\title{
On the Ways of Ideological and Political Education in Contemporary China's Colleges and Universities
}

\author{
Jiangping Liu \\ Public Security Fire Force College, Kunming 650208, China
}

Keywords: Colleges and universities, ideological and political education

\begin{abstract}
The way of ideological and political education in colleges and universities is the basic means of ideological and political education for educators. The ideological and political education in colleges and universities is an important aspect of ideological and political education. It is also an important subject that every educator should study. Educators should continue to innovate their educational channels and create a democratic and harmonious educational atmosphere for educators.
\end{abstract}

\section{The way of ideological and political education in colleges and universities}

The ideological and political education in colleges and universities is mainly aimed at college students and graduate students. It is a purposeful, planned and organized education for educators in order to realize their educational goals and teaching tasks, with the ideology, values and moral norms of social mainstream Influence, so that the educated person to become the community needs and have a certain sense of social education practice.

Iideological and political education means that in order to achieve a certain ideological and political education purposes, so that the content of ideological and political education can be carried out smoothly through the main way, ideological and political education in colleges and universities is to enable educators to better accept the world outlook, Values of education and put into action in line with the characteristics of colleges and universities and students with the characteristics of the way. College ideological and political education workers, including ideological and political theory courses, professional teachers, faculty counselors, student cadres, etc., they formed a network of ideological and political education, to create a suitable educational environment for students to grow.

\section{The Main Ways of Ideological and Political Education in Contemporary Chinese Universities}

\subsection{Attention to classroom teaching, the use of indoctrination education}

The so-called ideological and political education is the inculcation of educators to the front, directly and systematically educated educators, so that the formation of a firm ideals and beliefs, so as to improve the ideological and political quality of the educated. The theory of indoctrination is the way of education that our party has always insisted on. Nowadays, in the face of the ever-changing world and the immersion of Western thought, the Chinese Marxism must be widely recognized by the Chinese citizens, especially the nation's main force. China's colleges and universities have a special political elective class, all schools have set up the "basic principles of Marxism," "Mao Zedong Thought and the theoretical system of socialism with Chinese characteristics," "Outline of Modern Chinese History," "ideological and moral cultivation and legal basis" and "Form and policy" courses, full-time political theory teacher through a unified teaching materials and curriculum systematically instilled the Marxist outlook on life and values, and guide students to adhere to the theoretical system of socialism with Chinese characteristics, the mainstream ideology.

\subsection{Focus on improving the effect of ideological and political education through campus activities or social practice}

Ideological and political education is a kind of practical activity. Colleges and universities in order to make up for the ideological and political education classroom curriculum problems, in the use of ideological and political theory classroom teaching the main channel, but also increased students to participate in extracurricular activities and social opportunities, So as to enhance the influence of 
ideological and political education, and then improve the ideological and political education effect. Various educational and class educational activities are an obvious way to educate, such as the current affairs forum, the celebration of national celebrations, watching patriotic films and other visiting activities, social research activities and theme groups and so on. This increased the students' understanding of social reality, deepened the understanding of the meaning of labor and life, and cultivated a sense of social responsibility. School sports or other sports competitions have also become the best form of college students to cultivate the psychological quality of students, the competition embodied in the collective concept and sense of competition is the students only in the classroom difficult to understand.

\subsection{Using the Communication Media to Do Ideological and Political Education}

China attaches great importance to the guiding role of public opinion, books, newspapers, television, radio, and the network is a common communication tool in our lives. In the face of strong curiosity, to receive new things faster college students, colleges and universities should play an important role in the campus media, students in the form of happy to show the integration of ideas, knowledge and fun in one of the dissemination of content, so that students in the study of science Cultural knowledge at the same time to understand the social hot spots, accept ideological and political education.

With the help of multimedia, typical education has also become an important way to transmit social mainstream ideology and improve students' ideological consciousness. Typical education is through the typical people or things in life education, triggering the emotional resonance of the educated people to guide people to learn more people, more simple reasoning more infectious and acceptable.

\subsection{Paying Attention to the Work of Party Building in Colleges and Universities}

Oorganizational construction is one of the main ways of ideological and political education. Ideological and political education through party activities is the advantage and characteristics of our country. In the same way in colleges and universities, around the school party and government center work, the party can carry out "excellent group cadres", "outstanding party members", "advanced youth" selection and other rich party group construction activities, each college can also actively carry out the party School or salon activities, around the current social hot spots to discuss, to keep abreast of students' ideological trends, the bad thoughts slaughtered in the cradle.

\section{Reflections on the Ways of Ideological and Political Education in Contemporary China 's Colleges and Universities}

\subsection{China's colleges and universities focus on explicit education}

The main way for our students to carry out ideological and political education is that special educators through political public classes or by means of party organizations, with a more direct way to clearly tell the views or requirements of the educated, reflecting the distinctive politics Sexuality, planning. However, according to the characteristics of ideological and political education and the characteristics of college students, colleges and universities should pay more attention to the combination of explicit education and recessive education. In all courses, we should infiltrate the content of moral education. Not only in the public political class, attention to the effect of hidden courses. At the same time, pay attention to the implementation of ideological and political education path from the past to the diversification of diversification, broaden the ideological and political education dimensions.

\subsection{China's colleges and universities pay more attention to the guiding role of educators}

China in the development of thousands of years has always stressed that the national collective interests higher than personal interests, this concept is reflected in the ideological and political education approach is to attach importance to educators and light education object, emphasizing the dignity of teachers, and not pay attention to the subject of education But with the development of social democracy and the liberation of individuality, educators should pay more attention to the development of students' autonomy, pay attention to the self-examination of the educated people, that is to leave the educators more room for reflection, exercise Self-supervision and self-management ability, let it check their own virtue, the pursuit of higher moral standards, in fact, this is one of our 
traditional way of ideological and political education. The combination of the guiding role of the educator and the self - examination of the educated person has far - reaching significance in the contemporary colleges and universities that emphasize the development of the students' personality.

\subsection{China's psychological counseling institutions are not perfect}

The development of psychological counseling agencies in China has just gone through more than 10 years, most colleges and universities have to carry out psychological counseling work, many colleges and universities on the psychological counseling requirements are not very high, and engaged in the industry teachers of the degree of specialization is not very high, Therefore, most of our college's psychological counseling work is only a mere formality. But with the fierce competition in society and the increase of people's pressure, there are more and more people more or less there are some psychological problems or anxiety, so colleges and universities should pay attention to the psychological counseling of students in this work, the mental health Education is incorporated into the ideological and political education system of colleges and universities. Increase the financial investment in the construction of psychological counseling institutions, the construction of a full-time teachers, special combination, high quality mental health education and counseling team for the students' physical and mental health and improve the development of personality to provide protection.

\subsection{China's colleges and universities should pay more attention to the school ideological and political education and family, social cooperation}

School ideological and political education cannot rely on a small number of ideological and political education workers to complete, it should be the whole school and the whole society thing, is everyone's thing, because the growth of college students is related to the future of the motherland. Parents are the first to educate their children in all aspects, of course, including moral quality, attitude to life education, parents of words and deeds will have a profound impact on their children, family atmosphere also affect the child's personality development; The planned place for the education of students; social environment for the citizens of the world outlook, outlook on life and values of the formation and establishment is playing a vital role. Therefore, the various departments and organizations of society should form a comprehensive education network with the same goal, interaction and coordinated development, and play the role of education together to promote the optimization of the effect of ideological and political education.

The cooperation between ideological and political education and family education in colleges and universities can strengthen the connection between parents and parents through parental schools, communication with parents and other parents, introduce parents' performance in school, solicit the cooperation or opinions of parents on school moral education. Parents are also fully involved in the school moral education work, to discuss ideological and political education plans. At the same time, should give full play to the role of social public resources, the role of education, colleges and universities or parents can lead students to visit a variety of museums, historical sites, celebrities or participate in the quality of the expansion of training to enhance students' national pride and overall quality, Timely guide students to establish lofty ambitions.

\section{References}

[1]. Li Yang. Analysis of the similarities and differences between the implementation of ideological and political education in schools in China and the United States [D]. Northeast University of Finance and Economics, 2007

[2]. Yan Guixiang, Xu Bingqi. Adhere to the "three" principle to achieve "two courses" education and education with the times [J]. Education Theory and Practice, 2003 (03)

[3]. Tang Li. China's ideological and political education characteristics and enlightenment [J]. Journal of Nanjing University of Science and Technology, 2009 (02): 91 